\title{
Egészségkommunikációs Felmérés Eredményei II. - Iskolai felmérés
}

\author{
Results of the School Health Communication Survey I. - Student Survey
}

\author{
Szerzők: Zsíros Emese凶, Balku Eszter, Vitrai József \\ Nemzeti Egészségfejlesztési Intézet
}

Beküldve: 2016.06.23.

\begin{abstract}
Összefoglaló: Az iskolai Egészségkommunikációs Felmérés célja, hogy feltérképezze a 5., 7. és 9. osztályos magyar tanulók egészségmagatartását és az azt befolyásoló tényezőket. Módszertan: jelen elemzést országosan reprezentatív mintán végeztük, amely többlépcsős, rétegzett mintavételi eljárással készült. Az adatfelvétel az iskolai osztályokban, anonim módon, önkitöltős kérdőív segítségével és képzett kérdezőbiztosok irányítása mellett zajlott. A megvalósult mintát 7443 megfelelően kitöltött kérdőív alkotja. A kérdések lefedték az egészséggel kapcsolatos ismereteket, attitűdöket, motivációkat, a testi, és lelki egészséget, a pszichológiai tulajdonságokat, az egészségmagatartást, a társas támogatottságot, a kommunikációs szokásokat, az egészséggel kapcsolatos információkeresést valamint a megkérdezettek társadalmi-gazdasági jellemzőit. Eredmények: jelen cikkben bemutatjuk a vizsgálat leíró eredményeit. Összegzés: az egészséggel kapcsolatos viselkedés és az ezeket meghatározó képességek, motiváció és környezet ismeretében lehetővé válik a beavatkozások tervezése és a szükséges kommunikációs csatornák azonosítása.
\end{abstract}

Kulcsszavak: iskoláskorúak, egészségkommunikáció, viselkedésváltoztatás, COM-B modell

Summary: The School Health Communication Survey was planned to map the Hungarian 5th, 7th and 9th grade students' health behavior and the factors influencing it. Method: the current analysis was done within the Hungarian nationally representative sample which was drawn by the use of multi-stage, stratified cluster sampling technique. Data collection was carried out in classrooms, using anonymous self-reported questionnaires under the control of trained personnel. The cleaned sample contains 7443 questionnaires, filled in appropriately. The questions cover knowledge about and attitude to health, somatic and mental health status, psychological characteristics, health behaviors, social support, media consumption, health related information seeking, and socio-demographic characteristics. Results: this article presents the descriptive results of the survey. Discussion: in the light of information available on healthrelated behavior and its influencing factors such as capability, motivation and opportunity it is possible to plan interventions and to identify necessary communication channels.

Keywords: school-aged children, health communication, behavior change, COM-B model

\section{BEVEZETÉS}

Az iskoláskorúak az egészségfejlesztés kiemelt jelentőségű célcsoportját képezik. ${ }^{1}$ A serdülőkort hagyományosan olyan életszakasznak tekintik, amelyben az intenzív testi-lelki-szociális változások mel- lett folytatódik a különböző magatartásformák, szokások, életmód és egészségkultúra formálódása, megszilárdulása. ${ }^{2} \mathrm{Az}$ egészségükkel kapcsolatos viselkedések gyakoriságának figyelemmel követése segít meghatározni az egészségjavító beavatkozások célterületeinek kijelölését. 
A magyar fiatalok egészségi állapotára és egészségmagatartására vonatkozó vizsgálatok eredményei összességében nem adnak okot elégedettségre. Az iskoláskorú gyermekek fizikai aktivitása nem kielégítő mértékü. ${ }^{3}$ A képernyő előtt eltöltött (passzív) idő növekedésével párhuzamosan a testmozgás rendszeressége és a ráfordított idő mennyisége nem változott jelentősen az utóbbi években. Az egészséges táplálkozás nem választható el az egészséges mértékű fizikai aktivitástól. A túlsúly kialakulását elősegítő életmódbeli tényező a magas kalóriatartalmú, de alacsony tápértékű élelmiszerek gyakori fogyasztása. A táplálkozási szokásokban tapasztalt változások jó irányba mutatnak a 2014-es HBSC vizsgálat eredményei szerint: a zöldségfogyasztás terén növekvő, a gyümölcsfogyasztás terén stagnáló tendencia figyelhető meg, de a táplálékösszetételre vonatkozó adatok még mindig nagyon kedvezőtlennek mondhatók. Magas az édességet és a cukrozott üdítő italt rendszeresen fogyasztók aránya.

A serdülőkor az egészségkockázati magatartásformák, a különböző szerek kipróbálásnak normatív időszaka. Az egészséget veszélyeztető magatartások - többek között az alkohol és drogfogyasztási szokások - terén sem figyelhetők meg biztató tendenciák. ${ }^{2} \mathrm{Az}$ adott viselkedések és a háttértényezők közötti összefüggések feltárása útmutatást nyújthat abban, hogy hogyan, milyen beavatkozásokkal lehetne a felsorolt területeken kedvező változásokat elérni. Jelen közlemény célja, hogy bemutassa az Egészségkommunikációs Felmérés 5., 7. és 9.-es osztályos tanulókra vonatkozó leíró eredményeit.

\section{MÓDSZERTAN}

A felmérés tervezése során a felsorolt magatartásformák változtatására kidolgozott elméleti modellek szolgáltak alapul. Az áttekintett elméletek integrálásával Michie és munkatársai összegezték az egészségmagatartás és az azt befolyásoló tényezők összetett hatásrendszerét. ${ }^{4}$ Modelljük, a "viselkedésváltoztatás kereke” három meghatározó komponenst tartalmaz. A viselkedést befolyásoló „képesség" (Capability), azaz az egyénnek vagy a közösségnek a viselkedés megvalósításhoz szükséges testi és lelki készségei szabják meg. Az un. „motiváció” (Motivation), amelyet a cselekvést elindító tudatos döntések, szándékok és automatikusan adott válaszok, szokások alkotnak. A cselekvés megvalósulását a ",körülmények” (Opportunity), azaz a fizikai valamint a szociális-kulturális környezet is meghatározza. A COM-B modelli szerint a viselkedés visszahat a három befolyásoló tényezőre, és azok egymásra is hatással vannak. [1. ábra]

1. ábra: A viselkedés és az azt befolyásoló tényezök (COM-B modell) $)^{5}$

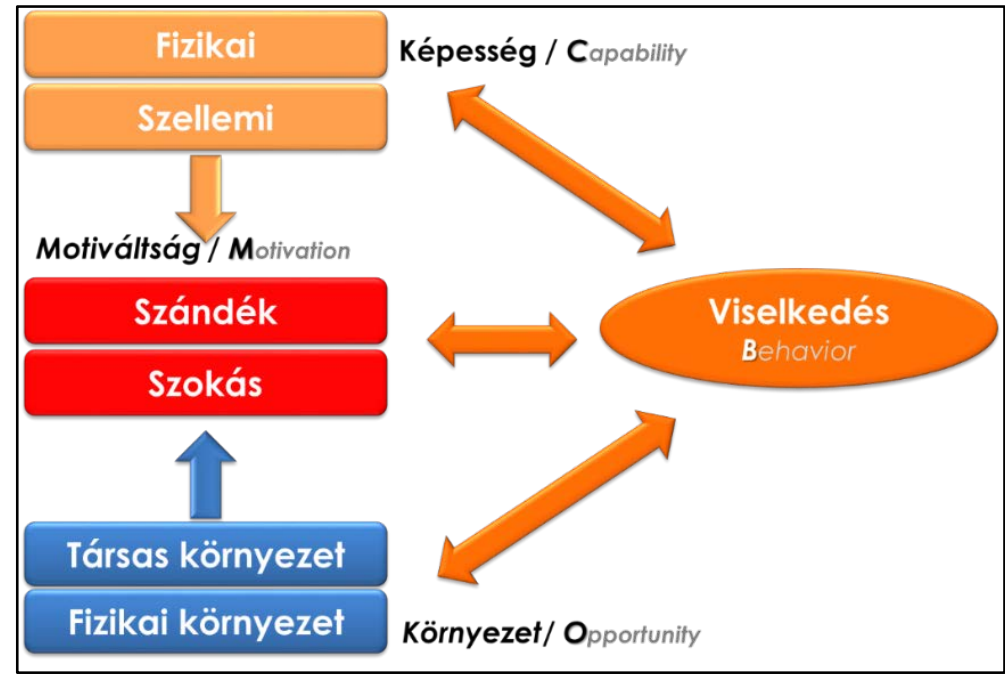

Forrás: Balku E, et al, (2015)

'A mozaikszó az angol Capability, Opportunity, Motivation és a Behaviour kifejezések kezdőbetűiből származik. 
A minta kiválasztása az Oktatási Hivatal oktatási intézményeket tartalmazó nyilvántartása alapján, véletlen, klaszter-alapú eljárással történt. A mintegy 150 településen véletlenszerűen kijelölt 450 iskola egy-egy osztályából összesen körülbelül 9000 gyerek került a mintába, reprezentálva a 2014/2015-ös tanévben 5., 7. és 9. évfolyamon tanuló magyar iskolásokat. A kérdéssort a kérdezőbiztosok jelenlétében 7443 tanuló anonim módon töltötte ki egy tanóra alatt. [1. táblázat] Az adatok súlyozása, reflektálva elsődlegesen a területi arányokra, a csoportosmintavételre, valamint a csoportok belső homogenitására, iteratív módon történt.
A kérdőívi kidolgozása több lépcsőben, kvantitatív (kérdőívek kitöltése tanulók kisebb csoportjával) és kvalitatív elővizsgálatokkal (fókuszcsoportok) zajlott. A felmérést szervező és végző munkacsoport az érintett korosztállyal foglalkozó szélesebb szakmai közeg bevonásával egyeztetéseket, nyílt fórumokat szervezett, ahol a szakemberek véleményezték a kérdőívet és javaslatot tehettek annak tartalmára. Az iskolai felmérés kérdőívének elméleti háttere a felnőtt felméréshez ${ }^{6}$ hasonló. A változók témaköreit a COM-B modell négy komponense mentén foglaltuk össze. [2. táblázat]

1. táblázat: A tervezett és megvalósult mintaelemszám évfolyam szerint

\begin{tabular}{|c|c|c|c|}
\hline Évfolyam & Minta & Válaszadók száma & $\begin{array}{c}\text { Megvalósult minta } \\
\text { Válaszadási arány }\end{array}$ \\
\hline 5. osztály & 3383 & 2326 & $69 \%$ \\
\hline 7. osztály & 3088 & 2363 & $77 \%$ \\
\hline 9. osztály & 4068 & 2754 & $68 \%$ \\
\hline Összesen & 10539 & 7443 & $71 \%$ \\
\hline
\end{tabular}

2. táblázat: táblázat: Iskolai felmérés kérdőivének témakörei és az egyes témakörök kérdéseinek száma a COM-B modell alapján ${ }^{i i i}$

\begin{tabular}{|c|c|c|c|c|}
\hline \multirow[b]{2}{*}{ COM-B elem } & \multirow[b]{2}{*}{ Témakör } & \multicolumn{3}{|c|}{ Kérdések száma } \\
\hline & & $\begin{array}{l}\text { 5. évfo- } \\
\text { lyam }\end{array}$ & $\begin{array}{l}\text { 7. évfo- } \\
\text { lyam }\end{array}$ & $\begin{array}{l}\text { 9. évfo- } \\
\text { lyam }\end{array}$ \\
\hline \multirow{4}{*}{ 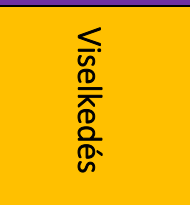 } & Egészségtelen táplálkozás³ & 8 & 8 & 8 \\
\hline & Rizikómagatartások $3,7,8,9$ & 5 & 5 & 8 \\
\hline & Médiafogyasztás ${ }^{3}$ & 9 & 9 & 9 \\
\hline & Információkeresés ${ }^{10}$ & 6 & 6 & 10 \\
\hline \multirow{5}{*}{ 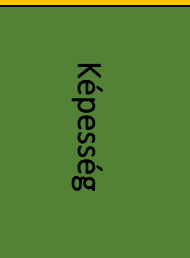 } & Szubjektív egészségi állapot ${ }^{3}$ & 1 & 1 & 1 \\
\hline & Egészségprobléma & 1 & 1 & 1 \\
\hline & Lelki egészség $^{11,12}$ & 12 & 12 & 12 \\
\hline & Énhatékonyság ${ }^{13}$ & - & 7 & 7 \\
\hline & Ismeretek $^{14,15}$ & 6 & 6 & 8 \\
\hline \multirow{10}{*}{ 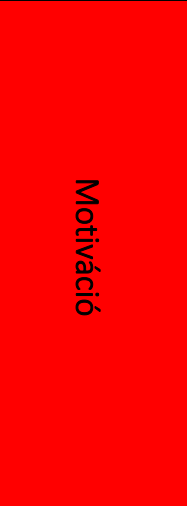 } & Külső megjelenés & 1 & 1 & 1 \\
\hline & Egészséggel való viszony ${ }^{16,17,18}$ & 6 & 6 & 6 \\
\hline & Egészségmagatartáshoz való viszony & 3 & 3 & 5 \\
\hline & Élettel való elégedettség ${ }^{8}$ & 1 & 1 & 1 \\
\hline & Szenzoros élménykeresés ${ }^{9}$ & - & 10 & 10 \\
\hline & Értékrend ${ }^{19,20,21}$ & - & 7 & 7 \\
\hline & Egészséggel kapcsolatos információforrás 21 & 6 & 6 & 10 \\
\hline & Tanulmányi teljesítmény ${ }^{21}$ & 1 & 1 & 1 \\
\hline & Iskolai kötődés ${ }^{22}$ & 8 & 8 & 8 \\
\hline & Egészséggel kapcsolatos tanulás ${ }^{23}$ & 5 & 5 & 5 \\
\hline
\end{tabular}

\footnotetext{
"A kérdőív a közlemény mellékletében elérhető.

iii A saját szerkesztésű kérdések mellett hivatkozást nem tüntettünk fel.
} 


\begin{tabular}{|c|c|c|c|c|}
\hline \multirow{7}{*}{ 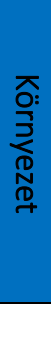 } & Családi jómódúság ${ }^{3}$ & 24 & 24 & 24 \\
\hline & Családi idő24,25,26 & 10 & 10 & 10 \\
\hline & Szülői kontroll & 7 & 7 & 7 \\
\hline & Szülői kapcsolat ${ }^{27}$ & 7 & 7 & 7 \\
\hline & Szerep, modell ${ }^{8,28}$ & 12 & 23 & 23 \\
\hline & Társas támogatás $10^{10}$ & 6 & 6 & 6 \\
\hline & Összesen: & 150 & 186 & 201 \\
\hline
\end{tabular}

Cikkünkben a legfőbb eredményeket mutatjuk be gyakorisági eloszlások, illetve évfolyam szerinti bontásban.

\section{EREDMÉNYEK}

$A z$ eredményeket az áttekinthetőség érdekében a felmérés alapját adó COM-B modell eleme alapján tagoljuk.

\section{Viselkedés}

\section{Egészségtelen táplálkozás}

A kérdőívben a diákokat a koffeintartalmú italok és az egészségkockázatot jelentő élelmiszerek fogyasztásáról kérdeztük. Az 5. osztályos tanulók a koffei- nes italok közül legnagyobb arányban teát fogyasztanak legalább hetente egyszer, de közel a felük minden nap fogyaszt valamilyen koffeintartalmú italt (kávét, teát, kólát, vagy energiaitalt). [3. táblázat] A 7. és 9. osztályos tanulók esetében is a tea a leggyakrabban fogyasztott koffeintartalmú ital, magasabb életkorban nagyobb azok aránya, akik naponta fogyasztanak valamilyen koffeintartalmú italt. A megkérdezett gyerekek az egészségkockázatot jelentő ételek közül legmagasabb arányban legalább hetente egyszer édességet fogyasztanak, az egyharmaduk minden nap fogyaszt valamilyen egészségkockázatot jelentő élelmiszert, azaz édességet, chipset, vagy valamilyen gyorséttermi ételt. [4. táblázat] Az egészségkockázatot jelentő élelmiszerek esetében is az édesség a leggyakrabban fogyasztott egészségkockázatot jelentő élelmiszer.

3. táblázat: A koffeintartalmú italok és az egészségkockázatot jelentő élelmiszerek heti fogyasztási gyakorisága (\%)

\begin{tabular}{|c|c|c|c|}
\hline \multicolumn{4}{|c|}{ Legalább hetente egyszer fogyaszt... } \\
\hline Fogyasztási gyakoriság \% & 5. osztály & 7 . osztály & 9. osztály \\
\hline Kávét & 13,4 & 21,9 & 40,7 \\
\hline Teát & 67,2 & 70,3 & 67,3 \\
\hline Kólát & 38,2 & 46,8 & 42,4 \\
\hline Energiaitalt & 9,1 & 20,9 & 28,7 \\
\hline Édességet & 68,9 & 74,6 & 71,7 \\
\hline Chipset & 55,4 & 58,0 & 51,8 \\
\hline Gyorséttermi ételt & 18,4 & 16,6 & 17,5 \\
\hline
\end{tabular}

4. táblázat: A koffeintartalmú italok és az egészségkockázatot jelentő élelmiszerek napi fogyasztási gyakorisága (\%)

\begin{tabular}{|c|c|c|c|}
\hline \multicolumn{4}{|c|}{ Naponta fogyaszt legalább egy... } \\
\hline Fogyasztási gyakoriság \% & 5. osztály & 7. osztály & 9. osztály \\
\hline $\begin{array}{c}\text { Koffeintartalmú italt (a teát } \\
\text { is beleértve) }\end{array}$ & 47,6 & 51,4 & 55,4 \\
\hline Egészségtelen élelmiszert & 32,9 & 36,8 & 33,7 \\
\hline
\end{tabular}




\section{Testsúlykontrolláló magatartás}

A tanulók egyharmada már 5.-es korában fogyókúrázott vagy próbált valamilyen módon lefogyni. Ez a hányad stabilan tartja magát az idősebb évfolyamokon is.

\section{Rizikómagatartások}

A diákokat a dohánytermékek használatáról, valamint az alkohol-, illetve drogfogyasztásról kérdeztük. A megkérdezett 5. osztályosok 4\%-a próbálta már ki a dohányzást ${ }^{i v}$ és $2 \%$-uk dohányzott is valamilyen rendszerességgel az elmúlt 30 napban. A 7. osztályosok 22\%-a gyújtott már rá valaha életében, és közel 10\%-uk gyújtott rá valamilyen rendszerességgel az elmúlt 30 napban. A 9. osztályosok több mint fele kipróbálta már és 33\%-a az elmúlt 30 napban dohányzott is valamilyen rendszerességgel.
[5. táblázat] Az 5. osztályosok 22\%-a, a 7. osztályosok 44\%-a, a 9. osztályosok $79 \%$-a ivott már valaha egy-két kortynál több alkoholt. Az ötödikesek 2\%-a, a hetedikesek $10 \%$-a és a kilencedikesek $19 \%$-a ivott alkoholt az elmúlt 30 napban. A káros egészségi, szociális és jogi következmények miatt kívánatos, hogy az iskolások minél kisebb hányada ismerkedjen meg a pszichoaktív szerekkel. A 9. osztályosoktól megkérdeztük, hogy fogyasztottak-e már valaha drogot $^{\vee}$ életükben (életprevalencia). 11\%-uk legalább egyszer fogyasztott már valamilyen drogot. $A z$ egészségüket veszélyeztető magatartásforma a védekezés nélküli és a korai szexuális élet. A megkérdezett 9. osztályosok 27\%-ának volt már szexuális kapcsolata. A legutóbbi alkalommal 78\%-uk használt valamilyen fogamzásgátló módszert.

5. táblázat: Dohányzás és alkoholfogyasztás gyakorisága (\%)

\begin{tabular}{|c|c|c|}
\hline Évfolyam & $\begin{array}{c}\text { Dohányzás } \\
\text { Az elmúlt } \begin{array}{c}\text { 30 napban dohányzott } \\
(\%)\end{array}\end{array}$ & $\begin{array}{c}\text { Alkohol } \\
\text { Az elmúlt } 30 \text { napban egy-két korty- } \\
\text { nál több alkoholt ivott (\%) }\end{array}$ \\
\hline 5. osztály & 2 & 2 \\
\hline 7. osztály & 10 & 10 \\
\hline 9. osztály & 33 & 19 \\
\hline
\end{tabular}

\section{Médiafogyasztás}

A tévénézés és a számítógépezés (játék és internethasználat) napi időtartamát kérdeztük a diákoktól, külön a tanítási és a hétvégi napokra vonatkozóan. Minden tevékenység esetében elmondható, hogy a hétköznapokhoz képest a hétvégén jóval több időt töltenek ezekkel a fiatalok. A diákok többnyire legfeljebb 2 órát néznek tévét a hétköznapokon $(52,7 \%)$, ugyanakkor közel negyedük $(23,9 \%)$ jelezte, hogy soha nem néznek tévét tanítási napokon. Mintegy 6\% azoknak az aránya, akik azonban 5 vagy több órát töltenek naponta tévénézéssel hét közben. Hétvégén a nem tévézők aránya erősen lecsökken $(9,7 \%)$, és ugyanez mondható el a legfeljebb 2 órát tévét nézőkről is (34,3\%). Legnagyobb arányú a hétvégi napokon naponta 3-4 órás tévézés $(36,2 \%)$, de minden ötödik $(19,8 \%)$ fiatal ennél is többet, legalább 5 órát néz tévét naponta hétvégéken. A diákoknak közel fele $(47,5 \%)$ egyáltalán nem játszik számítógépen tanítási napokon, és több mint harmaduk (37,6\%) legfeljebb 2 órát foglalkozik ezzel naponta. Csekély a tanítási napokon legalább napi 5 órát játszók aránya (4,6\%). Hétvégéken a napi legfeljebb 2 órát játszók hányada (32,1\%) a legmagasabb, és legkisebb - bár jóval nagyobb a hétköznapinál - a naponta legalább 5 órát számítógépes játékkal töltőké (17,6\%). Ugyanakkor a tanulóknak több mint egynegyede (27,5\%) hétvégéken soha nem játszik számítógépen. Az internethasználat (pl. email, facebook, honlapok, YouTube) jóval jellemzőbb a fiatalok körében, mint a játék. Tanítási napokon csak közel minden ötödik (18,7\%) diák számolt be arról, hogy egyáltalán nem internetezik. Legtöbbjük $(46,6 \%) 2$ óránál többet nem tölt ezzel na-

\footnotetext{
iv Dohányzás alatt értjük akár cigaretta, szivar, szivarka, pipa, vízipipa vagy elektronikus cigaretta szívását.

` Drog alatt értjük például a következők legalább egyikét: marihuána, hasis (fű, spangli); ecstasy, MDMA (diszkó tabletta); amfetamin (speed, spuri, gyorsító); alkohol gyógyszerrel együtt; gyógyszer, hogy feldobjon; ragasztó, oldószer (szipu); mágikus gomba; növényi drogok; dizájner drogok; egyéb drogok.
} 
ponta. Legkisebb a naponta legalább 5 órát internetezők aránya (14,5\%). Hétvégéken a fiataloknak csak 7,5\%-a nem használja az internetet. Hasonló arányban vannak a naponta legfeljebb 2 órát (34,0\%), a 3-4 órát $(29,4 \%)$ és a legalább 5 órát (29,0\%) a világhálón töltők. A megkérdezett tanulók kétharmada soha nem hallgat rádiót hétköznap (67\%) és valamivel több, mint felük hétvégén sem (56\%). Ez az arány viszonylag állandó mindhárom korosztálynál. [19. táblázat] Az iskolai munkán túl a diákok 68\%-a hétköznap és 72\%-a hétvégén is olvas könyvet. Könyvet és újságot az idősebb korosztályban kisebb arányban olvasnak. Míg az 5. osztályosok egyharmada havonta legalább egy könyvet olvas, addig ugyanezt csak a 9. osztályosok $24 \%$-a válaszolta. Újságot, magazint több mint felük olvas, jellemzően inkább hétvégén (62\%), mint hétköznap (57\%).
Információkeresés

Az 5., 7. és 9. osztályos tanulók az egészséggel kapcsolatos témák közül leggyakrabban a mozgás, testedzés témakörben keresnek információt. Az információt keresők aránya az életkor növekedésével nő, vagyis a 9.-es tanulók nagyobb arányban keresnek információt az egészséggel kapcsolatos témákban, mint az 5.-esek. Évfolyamtól függetlenül majdnem minden témában a családot tartják a legnagyobb arányban hiteles és elsődleges információforrásnak. A 9.-es diákok közül a mozgás, testedzés, valamint a párkapcsolat és szerelem témakörben jelöltek meg más elsődleges forrást, az előbbi esetében az internetet, az utóbbi esetében a barátokat tartják elsődleges forrásnak a legnagyobb arányban. [6. táblázat]

6. táblázat: Információt keresők aránya és a legnépszerübb információforrás

\begin{tabular}{|c|c|c|c|c|c|c|}
\hline \multirow[b]{2}{*}{ Témák } & \multicolumn{2}{|c|}{ 5. osztály } & \multicolumn{2}{|c|}{ 7. osztály } & \multicolumn{2}{|c|}{ 9. osztály } \\
\hline & $\begin{array}{l}\text { Keresők } \\
\text { aránya (\%) }\end{array}$ & $\begin{array}{l}\text { Legnépsze- } \\
\text { rűbb forrás }\end{array}$ & $\begin{array}{c}\text { Keresők } \\
\text { aránya (\%) }\end{array}$ & $\begin{array}{l}\text { Legnépsze- } \\
\text { rűbb forrás }\end{array}$ & $\begin{array}{l}\text { Keresők } \\
\text { aránya } \\
\text { (\%) }\end{array}$ & $\begin{array}{l}\text { Legnépsze- } \\
\text { rübb forrás }\end{array}$ \\
\hline $\begin{array}{c}\text { Étkezés, ételek, diétázás, } \\
\text { fogyókúrázás }\end{array}$ & 13,7 & Család & 17,2 & Család & 22,8 & Család \\
\hline Mozgás, testedzés, sportok & 54,0 & Család & 48,2 & Család & 46,3 & Internet \\
\hline Dohányzás & 2,8 & Család & 4,3 & Család & 9,6 & Család \\
\hline Alkoholfogyasztás & 2,7 & Család & 3,7 & Család & 7,7 & Család \\
\hline $\begin{array}{c}\text { Családi, baráti probléma, } \\
\text { konfliktus }\end{array}$ & 11,3 & Család & 13,2 & Család & 17,9 & Család \\
\hline $\begin{array}{c}\text { Iskolai probléma (szekálás } \\
\text { osztálytársak vagy tanárok } \\
\text { részérôl, stressz) }\end{array}$ & 13,6 & Család & 15,6 & Család & 14,7 & Család \\
\hline $\begin{array}{c}\text { Nemi szervek, múködésük, } \\
\text { szex, fogamzásgátlás }\end{array}$ & - & - & - & - & 11,9 & Család \\
\hline $\begin{array}{c}\text { Szexuális úton terjedő be- } \\
\text { tegségek, HPV oltás }\end{array}$ & - & - & - & - & 8,2 & Család \\
\hline Párkapcsolat, szerelem & - & - & - & - & 31,9 & Barátok \\
\hline Drogok és hatásaik & - & - & - & - & 7,4 & Család \\
\hline
\end{tabular}

\section{Képesség}

Vélt egészségi állapot és tartós egészségprobléma Az 5. osztályos tanulók közel háromnegyede (73\%) jónak vagy kitűnőnek értékelte egészségét, ez az arány a magasabb évfolyamokon rendre alacsonyabb, $68 \%$ és $65 \%$. A megkérdezettek nem elhanyagolható kisebbsége, 7\%-a él olyan tartós betegséggel vagy egészségi problémával, ami befolyásolja iskolába járását, iskolai munkában való részvételét. 


\section{Tápláltsági állapot}

A testtömeg-indexet - angolul body mass index, ismert rövidítéssel $\mathrm{BMI}$ - a testmagasságból és a testsúlyból számítottuk ki. ${ }^{\text {vi }}$ Az 5 . osztályosok $22 \%$-a, a 7. osztályosok $26 \%$-a és a 9. osztályosok $29 \%$-a túlsúlyos vagy elhízott.

\section{Lelki egészség}

A mentális egészség mérésére az általános egészség-kérdőivet (General Health Questionnaire GHQ-12) kérdőívet használtuk. ${ }^{11} \mathrm{~A}$ lelki egészség zavarainak szürésére használt, 12 tételes kérdőív a pszichiátriai-morbiditás globális komponenseire koncentrál, különösen a hangulati/szorongásos és az érzelmi zavarokkal járó mentális egészségproblémákra. Minél gyakrabban észleli a kitöltő a felsorolt tüneteket, annál nagyobb a valószínűsége a mentális funkcionalitás csökkenésének. Ezek jelenléte nem diagnosztikus értékű, de a serdülőkorúak esetében jelentős pszichológiai distresszt jelentenek, és az életvitelt jelentős mértékben akadályozhatják. ${ }^{29} \mathrm{~A} \mathrm{GHQ}$ skála átlaga a teljes mintán 2,20 $(S D=2,92)$. vii Az összesített eredmények alapján a 11-15 éves tanulók 18,7\%-a veszélyeztetett, viii vagyis túlzott mértékú pszichés stresszről számol be. Az 5. évfolyamosok $17 \%$-a, és már minden ötödik 9.-es elérte a kritikus értéket.

\section{Énhatékonyság}

E fogalom konstruktuma a személy optimista, saját magába vetett hitét tükrözi. ${ }^{13} \mathrm{Ha}$ egy személy magas énhatékonysággal bír, hisz abban, hogy képes újszerű vagy nehéz feladattal is megbirkózni, illetve a csapásokkal szembenézni az élet különböző területein. Ez pszichés védelmünk egyik pozitív erőforrása; megkönnyíti a célok kitűzését, az erőfeszítést, kitartást az akadályokkal szemben és a felépülést a kudarcok után. A kérdőív tíz tételét úgy fejlesztették ki, hogy minden eleme a sikeres megküzdésre és a siker belső, stabil attribúciójára vonatkozik. A 9. osztályosok átlagpontszáma 24,2 (SD=4,9). ${ }^{\text {ix }}$

\section{Ismeretek}

A megkérdezett tanulók közel fele tartja az egészséget természetesnek gyermekkorban. Túlnyomó többségük igaznak tartja az állítást, hogy a mozgás segít az egészség megőrzésében, többségük egyetért az alkohol fogyasztás káros hatásával és a reggelizés fontosságával is. A diákok csupán 23\%-a gondolta, hogy ha az ember egyszer-kétszer rágyújt, akkor azzal még nem veszélyezteti az egészségét. A 9. osztályosok 86\%-a nem értett egyet azzal, hogy a drog kipróbálása még nem károsítja az egészséget és $13 \%$-uk gondolta, hogy a különböző fogamzásgátló módszerek egyformán hatásosak. [7. táblázat]

7. táblázat: Egészséggel kapcsolatos állitások megitélésének megoszlási aránya (\%)

\begin{tabular}{|c|c|c|c|}
\hline \multirow{2}{*}{ Egészséggel kapcsolatos állítások } & \multicolumn{3}{|c|}{ Igaznak vagy nagyon igaznak tartja (\%) } \\
\hline & 5. osztály & 7. osztály & 9. osztály \\
\hline Gyerekkorban még természetes az egészség. & 55 & 52 & 50 \\
\hline $\begin{array}{l}\text { Fontos, hogy a diákok mindig reggelizzenek, mielőtt is- } \\
\text { kolába mennek. }\end{array}$ & 80 & 75 & 69 \\
\hline $\begin{array}{l}\text { Ha az ember egyszer-kétszer rágyújt, azzal nem veszé- } \\
\text { lyezteti az egészségét. }\end{array}$ & 24 & 21 & 23 \\
\hline A sok mozgás segít az egészség megőrzésében. & 93 & 93 & 92 \\
\hline $\begin{array}{l}\text { Az emberek kockáztatják az egészségüket, amikor alko- } \\
\text { holt fogyasztanak. }\end{array}$ & 86 & 71 & 57 \\
\hline $\begin{array}{l}\text { A lelki egészség azt jelenti, hogy az ember nem problé- } \\
\text { mázik, idegeskedik dolgokon, és többnyire elégedett. }\end{array}$ & 61 & 64 & 66 \\
\hline $\begin{array}{c}\text { A drog kipróbálása még nem veszélyezteti az ember } \\
\text { egészségét. }\end{array}$ & - & - & 14 \\
\hline $\begin{array}{c}\text { A különböző fogamzásgátló módszerek egyformán biz- } \\
\text { tonságosak. }\end{array}$ & - & - & 13 \\
\hline
\end{tabular}

\footnotetext{
vi A túlsúly megállapításához a Magyar Védőnők Egyesülete által kiadott „3. sz. Módszertani levél; Útmutató és táblázatok a gyermekkori tápláltság megítéléséhez" c. szakanyag került felhasználásra. Forrás: http://www.ogyei.hu/upload/files/gyermekkoriTaplaltsag.pdf (Elérve: 2016.09.24.)

vii A skála terjedelme: 0-12 pont.

viii 5 vagy annál magasabb pontszámot ért el.

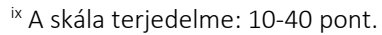




\section{Motiváltság}

Különböző egészségmagatartási formák fontosságának megítélése

A felsorolt viselkedéses területek közül a mozgás, sportolás, testedzés megítélésben volt a legnagyobb egyetértés a diákok között, 88\%-uk tartja ezt fontosnak. Közel 35\%-uk számára fontos vagy nagyon fontos a passzív időtöltés, a számítógépezés, elektromos játékok használata és a tévénézés is. [8. táblázat] A különböző évfolyamokon tanulók véleménye eltér az egészség fontosságát illetően. Míg a megkérdezett 5. osztályosok 84\%-a tartja fontosnak, hogy különbséget tegyen egészséges és nem egészséges között, addig a 9.-esek már csak 62\%ára igaz ugyanez. Hasonlóan egyre kisebb köztük az egészségtelen (túl zsíros vagy sok cukrot tartalmazó) ételek kerülésével egyetértők aránya. A lelki egészség megóvását szolgálja, ha a fiatal úgy érzi, beszélhet valakivel a környezetében akár gondjairól, akár az őt foglalkoztató kérdésekről. Ezt életkortól függetlenül a diákok körülbelül kétharmada (64\%) tartotta fontosnak.

8. táblázat: Különböző egészségmagatartási formák fontosságának megoszlási aránya (\%)

\begin{tabular}{|c|c|c|c|}
\hline \multirow{2}{*}{ Egészségmagatartással kapcsolatos állítások } & \multicolumn{3}{|c|}{ Fontosnak vagy nagyon fontosnak tartók aránya (\%) } \\
\hline & 5. osztály & 7. osztály & 9. osztály \\
\hline $\begin{array}{c}\text { Mennyire fontos, hogy mi egészséges és mi } \\
\text { nem. }\end{array}$ & 84 & 72 & 62 \\
\hline $\begin{array}{c}\text {...kerüld az egészségtelen, mint pl. túl zsíros } \\
\text { vagy sok cukrot tartalmazó ételeket }\end{array}$ & 67 & 56 & 45 \\
\hline $\begin{array}{c}\text {... inkább cukormentes üdítőket, mint cukro- } \\
\text { sakat igyál }\end{array}$ & 54 & 40 & 35 \\
\hline $\begin{array}{c}\text {... számítógépezz, elektronikus játékokat } \\
\text { játssz, tévét nézz }\end{array}$ & 34 & 34 & 37 \\
\hline ... mozogj, sportolj, testedzést végezz & 92 & 89 & 83 \\
\hline $\begin{array}{c}\text {... beszélj valakinek a gondjaidról, a téged fog- } \\
\text { lalkoztató kérdésekről }\end{array}$ & 62 & 62 & 67 \\
\hline
\end{tabular}

\section{Attitűd}

A diákok igen kis százaléka értett egyet azzal, hogy a cigizés menő (3\%). [9. táblázat] Ennél többen értettek egyet azzal (5\%), hogy a drog segít jól érezni magukat a buliban és életkoronként egyre nagyobb mértékben értenek egyet abban, hogy az alkohol segít ellazulni. Az 5. osztályosokhoz képest a 9.-esek közül négyszer annyian értettek egyet ezzel az állí- tással ( $5 \%$ vs. $23 \%$ ). A megkérdezettek $15 \%$-a gondolja gyengeségnek a panaszkodást.

\section{Életcélok, értékek}

A 7. és 9. osztályos tanulók az életcélok fontosságát tekintve hasonlóan gondolkoznak, mindkét életkorban a fiatalok a három legfontosabb életcélnak a karriert, a szerelmet és az önmegvalósítást tartják. [10. táblázat]

9. táblázat: Az egészséggel kapcsolatos attitüd megitélése (\%)

\begin{tabular}{|c|c|c|c|}
\hline & \multicolumn{3}{c|}{ Egyet ért vagy teljes mértékben egyet ért (\%) } \\
\hline & 5. osztály & 7. osztály & 9. osztály \\
\hline A panaszkodás a gyengeség jele. & 17 & 14 & 14 \\
\hline Aki cigizik, az menő. & 3 & 3 & 3 \\
\hline Az alkohol segít ellazulni, felszabadulttá tesz. & 5 & 9 & 23 \\
\hline A drog segít, hogy jól érezd magad a buliban. & - & - & 8 \\
\hline Ciki óvszert vásárolni. & - & - & 11 \\
\hline
\end{tabular}


10. táblázat: Az életcélok fontosságának megoszlás aránya (\%)

\begin{tabular}{|c|c|c|}
\hline Életcél & 7. osztály (\%) & 9. osztály (\%) \\
\hline Szerelem & 76,2 & 84,5 \\
\hline Karrier & 76,4 & 81,7 \\
\hline Önmegvalósítás & 74,1 & 77,8 \\
\hline Pénz & 64,6 & 67,9 \\
\hline Mások tisztelete & 62,5 & 70,3 \\
\hline Népszerúség & 31,6 & 33,3 \\
\hline Hatalom & 21,0 & 27,7 \\
\hline
\end{tabular}

\section{Élettel való elégedettség}

A jóllét globális értékelésére vonatkozó mutató az élettel való elégedettség. A 0-tól 10-ig terjedő skála két végpontja a lehető legjobb és legrosszabb életet szimbolizálja. ${ }^{17} \mathrm{~A}$ diákok így a tizenegy válaszlehető- séget kínáló skálán jelölhették, mennyire elégedettek életükkel. Az 5. osztályosok átlagosan 7,8 ( $S D=1,8)$, a 7. osztályosok 7,2 (SD=1,8), míg a 9. osztályosok 6,8 $(S D=1,8)$ pontra értékelték. [2. ábra]

\section{2. ábra: 5.,7.,9. osztályos tanulók élettel való elégedettsége}

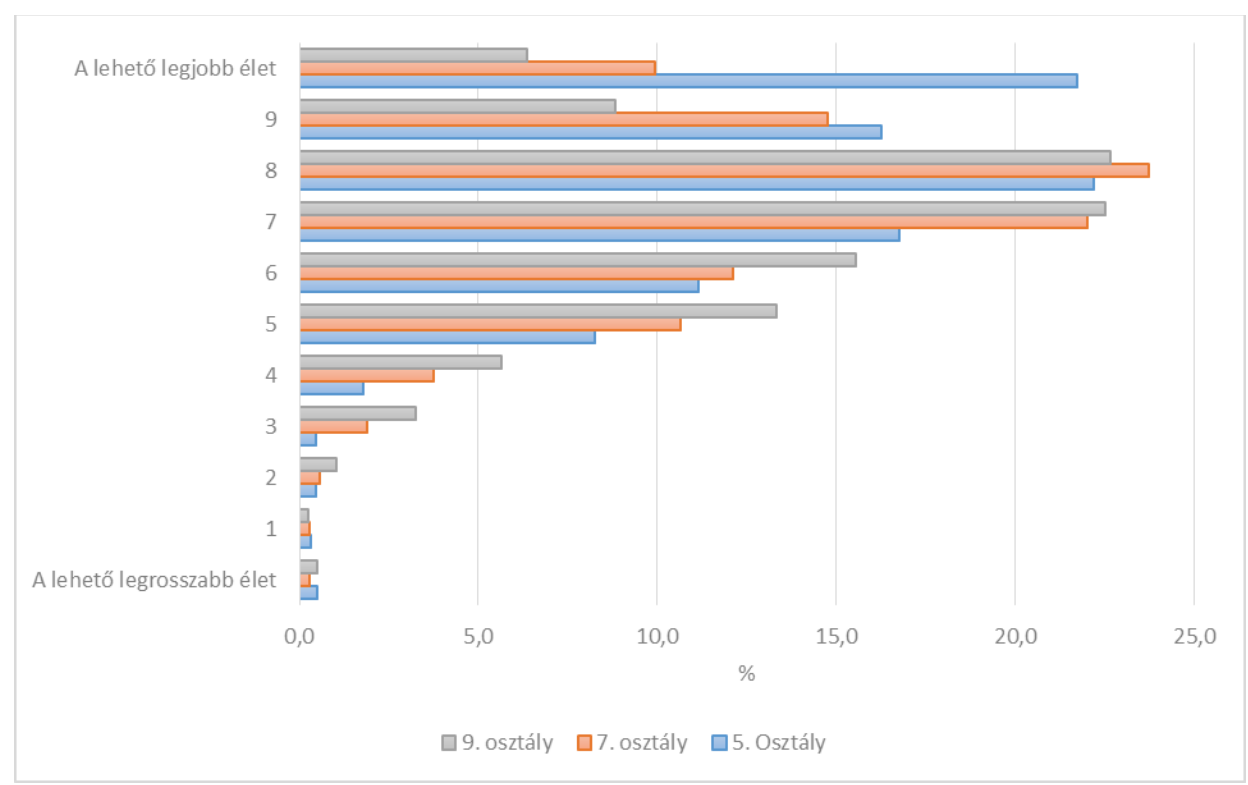

\section{Szenzoros élménykeresés}

A szenzoros élménykeresés, mint személyiségvonás, a változatos és új ingerek keresésére való hajlamot jelenti. ${ }^{30} \mathrm{~A}$ magas szenzoros élménykereséssel jellemezhetők szívesebben választanak olyan tevékenységeket, amelyek segítségével intenzív és komplex élmények, érzések érhetik őket, még akkor is, ha ezek valamilyen szempontból kockázatosak. ${ }^{12}$ A kérdéssort csak a két idősebb évfolyamon tanulók kérdőíve tartalmazta. A skála terjedelme 0-40 pont, a 7. évfolyamosok átlagpontszáma $16,2(S D=8,3)$, a 9.-eseké 18,5 (SD=8,3).

\section{Iskolai kötődés}

Az iskolához való viszony alatt azt értjük, hogy a gyermek szereti, várja az iskolát, az ott tanultakat kíváncsisággal, érdeklődéssel fogadja. A 11-15 éves diákok majdnem fele (47\%) átlagos módon viszonyul iskolájához, negyedük (27\%) kevésbé érzi jól magát az iskolájában. Az utóbbi megállapítás aránya életkorral nő. [11. táblázat] 
11. táblázat: Iskolai kötödés megoszlási aránya (\%)

\begin{tabular}{|c|c|c|c|}
\hline Iskolai kötődés szintje & 5. osztály (\%) & 7. osztály (\%) & 9. osztály (\%) \\
\hline Alacsony & 19 & 25 & 29 \\
\hline Normál & 42 & 49 & 51 \\
\hline Magas & 39 & 36 & 20 \\
\hline
\end{tabular}

Motivációk az egészséggel kapcsolatos ismeretek elsajátítására

Az egészséggel kapcsolatos tantárgyak iránti érdeklődés területén jobban szórnak a vélemények. Az 5 . osztályos tanulók $48 \%$-a, a 7.-esek $40 \%$-a és a 9.esek 39\%-a nagyon motivált, hogy az emberi test felépítéséről, működéséről, egészségéről és a betegségekről többet hallhasson az iskolában. Minden harmadik diák azonban kevéssé élvezi, ha ilyen témákban kap új információt. [12. táblázat]
Testkép

A fizikai megjelenéssel való elégedettség fontos öszszetevője a serdülőkorúak szubjektív jóllétének. Az intenzív testi változások időszakában fokozottá válik a megjelenés iránti érdeklődés, a kulturális és társadalmi normák és elvárások pedig tovább árnyalják a külsejükkel kialakított érzelmi viszonyulást. A tanulók legnagyobb arányban átlagosan jól néznek ki (48\%), 21\%-uk szerint nem, vagy egyáltalán nem néznek ki jól. [13. táblázat]

12. táblázat: A tanulók egészséggel kapcsolatos tanulásmotivációjának megoszlási aránya (\%)

\begin{tabular}{|c|c|c|c|}
\hline $\begin{array}{c}\text { Egészségről való tanulás iránti motiváció } \\
\text { szintje }\end{array}$ & 5. osztály (\%) & 7. osztály (\%) & 9. osztály (\%) \\
\hline Alacsony & 31 & 34 & 34 \\
\hline Normál & 21 & 26 & 27 \\
\hline Magas & 48 & 40 & 39 \\
\hline
\end{tabular}

13. táblázat: Külső megjelenéshez való viszony megoszlása 9. osztályosok körében (\%)

\begin{tabular}{|c|c|c|c|c|}
\hline $\begin{array}{c}\text { Nagyon jól nézek } \\
\text { ki (\%) }\end{array}$ & $\begin{array}{c}\text { Elég jól nézek ki } \\
(\%)\end{array}$ & $\begin{array}{c}\text { Átlagosan jól né- } \\
\text { zek ki (\%) }\end{array}$ & $\begin{array}{c}\text { Nem nagyon jól } \\
\text { nézek ki (\%) }\end{array}$ & $\begin{array}{l}\text { Egyáltalán nem né- } \\
\text { zek ki jól (\%) }\end{array}$ \\
\hline 11 & 19 & 48 & 15 & 6 \\
\hline
\end{tabular}

\section{Környezet}

\section{Minőségi idő a családdal}

Két kérdéscsoporttal vizsgáltuk, hogy a tanulók mennyi időt töltenek együtt szüleikkel. Az első, hat tételből álló csoportban a tanulók arra válaszoltak, hogy a hét napján végeznek-e szüleikkel otthoni vagy a ház körüli, mindennapi tevékenységeket. Szakirodalmi adatok alapján a heti gyakoriságnál ritkább együttlét egyértelműen kedvezőtlen egészségi hatásokkal jár. ${ }^{31}$ A szülőkkel való közös aktivitások gyakoriság szerinti sorrendje: vacsorázás (a tanulók 55,3\%-a, tehát több mint fele vacsorázik együtt legalább a hét 5 napján szüleivel) közös tévénézés, kultúrafogyasztás (41,1\%), közösen végzett házimunka (33,4\%), közös tanulás (23\%), együttes játék, spor- tolás (18,7\%), együtt végzett kerti munka (17,2\%). A közös aktivitások másik kérdéscsoportja olyan aktivitásokra vonatkozik, amelyek az otthontól viszonylag távol zajlanak, nem minden nap történnek. Ezeknél a lehetséges válaszkategóriák nem a heti gyakoriságra vonatkoznak, hanem a „soha” lehetőségtől a „hetente többször"-ig terjednek. Itt nem áll rendelkezésünkre előzetes szakirodalmi adat az egyes gyakoriságokkal társuló egészségről, de - az előbbi kérdéscsoport analógiájára - feltételezhetjük, hogy a „soha” és „évente” lehetőségek egyértelműen kedvezőtlen, míg a „körülbelül havonta” és „hetente többször" egyértelműen kedvező egészségi kimenettel függenek össze. A nem ház körüli tevékenységeknek ${ }^{x}$ az arányában nagy a változatosság. A tanulók mintegy háromnegyede $(72,4 \%)$ számol be ar-

\footnotetext{
× A szülőkkel együtt végzett ház körüli és extramurális (az otthon „falain” kívüli) tevékenységek gyakoriságának értelmezésénél nem szabad figyelmen kívül hagyni a nemi különbségek és a család jómódúságának hatását.
} 
ról, hogy legalább havonta együtt vásárolnak a szülővel; mintegy harmaduk $(29,6 \%)$ vesz részt a szülővel aktív kikapcsolódást nyújtó programban. Negyedük vesz részt legalább havonta kulturális eseményen $(24,8 \%)$, és tizedük megy nyaralni vagy történelmi látványosságokat megtekinteni szülójével vagy szüleivel $(10,1 \%)$.

\section{Szülői kapcsolat}

A szülői kapcsolat minőségét a serdülő problémáinak, az ôt érdeklő és foglalkoztató dolgok megosztása fémjelzi. A társas támogatás erre kialakított kérdéssora kiterjed többek között az iskolai és tár- sas problémákra, konfliktusokra, és a jövőbeli tervekre is. Általában elmondható, hogy minél idősebb a tanuló, annál ritkábban fordul bizonyos témák mentén szüleihez. ${ }^{x i} \mathrm{~A}$ különböző témák közül a baráti konfliktusok nehézségét és az alkohol, drogok kapcsán felmerült kérdéseket osztják meg a legritkábban. A leginkább a jövőbeli tervek kapcsán és a házi feladat kapcsán fordulnak szüleikhez. Körülbelül azonos azok aránya, akik szinte sohasem fordulnak szüleikhez akkor, ha igazán mérgesek, vagy kiborultak valami miatt (15\%) illetve, ha rosszul érzik magukat, búntudatuk van (17\%).[14. táblázat; részletesebben lásd 20. táblázat]

14. táblázat: Szülői kapcsolatok megitélésnek megoszlása (\%)

\begin{tabular}{|c|c|c|c|}
\hline & \multicolumn{3}{|c|}{$\begin{array}{c}\text { Szinte soha nem fordul elö, hogy az alábbi helyzetek- } \\
\text { ben szüleihez (nevelőszüleihez) fordul (\%) }\end{array}$} \\
\hline & 5. osztály & 7. osztály & 9. osztály \\
\hline $\begin{array}{l}\text { nehézségeid lennének a házi fel- } \\
\text { adattal, }\end{array}$ & 9 & 14 & 25 \\
\hline $\begin{array}{c}\text { szeretnél találni egy jó könyvet vagy } \\
\text { filmet, } \\
\end{array}$ & 12 & 20 & 30 \\
\hline a jövőbeli terveiden gondolkoznál, & 13 & 7 & 9 \\
\hline $\begin{array}{c}\text { összevesznétek a legjobb barátod- } \\
\text { dal, }\end{array}$ & 36 & 40 & 40 \\
\hline $\begin{array}{l}\text { szeretnél valamit megtudni az alko- } \\
\text { holról vagy drogokról, }\end{array}$ & 72 & 55 & 49 \\
\hline $\begin{array}{l}\text { igazán mérges lennél vagy kiborulnál } \\
\text { valami miatt, } \\
\end{array}$ & 11 & 16 & 19 \\
\hline $\begin{array}{l}\text { valami miatt rosszul éreznéd magad } \\
\text { vagy büntudatod lenne }\end{array}$ & 13 & 17 & 22 \\
\hline
\end{tabular}

\section{Szülői kontroll}

A tanulók 96\%-a szerint szüleik tudnak a tévénézéssel és internetezéssel töltött idejük mennyiségéről. Abban viszont különböznek a szülők, hogy ezt rábízzák-e gyermekükre vagy korlátozzák, esetleg tiltják is azt. Az adatokból látható, hogy míg az 5. osztályosok szülei inkább korlátozzák, a 7. és 9. osztályosok szülei már inkább gyermekükre bízzák a döntést. $A$ hazaérkezés időpontját illetően csak a 9. osztályosok között válik hasonlóvá a korlátozó és megengedő szülők aránya (47\% vs. 49\%), alacsonyabb életkorban inkább a kontrollálás és tiltás jellemző. Az édességfogyasztásról a szülők 91\%-a tud, az 5. évfo- lyamos tanulók szüleinek 51\%-a még korlátozza, míg a 7.-esek 33\%, a 9.-esek 15\%-a korlátozza. A szülők 90\%-a tud arról, hogy kikkel barátkozik, és mivel tölti a szabadidejét gyermekük. Ebben a két kérdésben függetlenül a gyermek életkorától jellemzőbb, hogy gyermekeikre bízzák a döntést. A dohányzás és alkoholfogyasztás alacsonyabb életkorban elenyésző. A szülők inkább korlátozzák vagy tiltják ezeket, a legidősebbek 9-10\%-ának szülei nem is tudnak róla. A serdülők 2\%-a úgy gondolja, hogy szüleiket nem is érdekli, ha gyermekük dohányzik vagy alkoholt fogyaszt.

\footnotetext{
xi Fontos, hogy bizonyos rizikómagatartások előfordulása életkori jellemző. Vagyis egy adott téma kapcsán előfordulhat, hogy adott életkorban még nem volt megosztanivalója szüleivel a gyermeknek.
} 


\section{Családi minta}

Minden második 11-15 éves diák családjában van olyan fontos személy, aki tartós betegséggel él. 56\%-uk környezetében van rendszeresen dohányzó, 10\%-uk környezetében alkoholproblémával küzdő, 15\%-ukéban gyakran lehangolt, depressziós személy. A diákok 42\%-a szerint családjában van fogyókúrázó. A pozitív minták nagy arányban vannak jelen a családokban, 69\%-uk találkozik rendszeresen sportoló, 79\%-uk egészségesen táplálkozó családtaggal. [15. táblázat; részletesebben lásd 21. táblázat]

15. táblázat: Családi minta megoszlása

\begin{tabular}{|c|c|c|c|}
\hline Minta & Azok aránya, akinek van ilyen személy a családjában (\%) \\
\hline $\begin{array}{c}\text { Tartós betegséggel vagy más egészségügyi problé- } \\
\text { mával, mint pl. cukorbetegséggel, szivbetegséggel, } \\
\text { mozgásszervi betegséggel, asztmával vagy széna- } \\
\text { náthával él? }\end{array}$ & 5. osztály & 7. osztály & \\
\hline Rendszeresen dohányzik? & 49 & 50 & 56 \\
\hline Alkoholproblémái vannak? & & & \\
\hline Fogyókúrázik? & 48 & 57 & 63 \\
\hline Rendszeresen sportol? & 7 & 10 & 13 \\
\hline Odafigyel arra, hogy egészségesen táplálkozzon? & 46 & 42 & 39 \\
\hline Gyakran lehangolt, depressziós? & 74 & 70 & 64 \\
\hline
\end{tabular}

Baráti és osztálytársi kapcsolatok

A kérdőívben a közeli barátok számát és a tőlük kapott társas támogatás mértékét kérdeztük. Évfolyamtól függetlenül az 5., 7. és 9. osztályosok 99\%nak legalább 1 barátja van. A tanulók több, mint fele (55\%) szerint szinte mindig érdekli a barátait, hogy mit gondol, és hogyan érez. [16. táblázat] Az idősebb tanulók magasabb arányban észlelik társaik érdeklődését, odafordulását.

\section{Baráti minta}

A tanulókat baráti és osztálytársi környeztükben lévők magatartásáról, illetve annak észleléséről kérdeztük. Míg az 5. osztályos diákok társai között 1-2\% dohányzik vagy iszik alkoholt, addig a 7. osztályosok között ennek tízszerese (14\% és 11\%), 9. osztályra pedig közel kétharmaduk (62\% és 60\%) érintett. Kisebb mértékü emelkedést mutat az életkor előrehaladtával a fogyókúrázó kortársak aránya. [17. táblázat] A megkérdezett 7. osztályosok 8\%-ának, a 9. osztályosok 43\%-ának van olyan kortársa, akinek már volt valaha szexuális kapcsolata. A 7. osztályosok között 4\%, a 9. osztályosok között 9\% a marihuánát fogyasztó barátokról vagy osztálytársakról beszámolók aránya. A növekvő tendenciát a rizikómagatartások előfordulási gyakorisága is magyarázza. A sportoló barátok és osztálytársak magas száma mindhárom korosztályra jellemző. A 7. évfolyamosok háromnegyedének (78\%) van olyan barátja vagy osztálytársa, aki rendszeresen sportol. Az egészségesen táplálkozó kortársak aránya az életkorral csökken, az 5. osztályosok fele (51\%) rendelkezik ilyen társsal, a 9.-esek között már csak egyharmaduk (36\%).

\section{Osztálylégkör}

A diákok 92\%-a szerint az osztálylégkör nagyon kedvező, vagyis osztálytársai szívesen vannak együtt, többségük segítőkész és elfogadják őt, olyannak amilyen. [18. táblázat]

16. táblázat: Társas támogatás megoszlása (\%)

\begin{tabular}{|c|c|c|c|}
\hline $\begin{array}{c}\text { Milyen gyakran érdekli a barátait, hogy } \\
\text { mit gondol, hogyan érez? }\end{array}$ & 5. osztály & 7. osztály & 9. osztály \\
\hline Szinte mindig & 45 & 56 & 66 \\
\hline Néha & 40 & 34 & 28 \\
\hline Nagyon ritkán & 15 & 11 & 6 \\
\hline
\end{tabular}


17. táblázat: Baráti és osztálytársi minta

\begin{tabular}{|c|c|c|c|}
\hline & \multicolumn{3}{c|}{ Azok aránya, akiknek van a barátai, osztálytársai között olyan, } \\
\hline & 5. osztály (\%) & 7. osztály (\%) & 9. osztály (\%) \\
\hline Dohányzik & 2 & 14 & 62 \\
\hline Alkoholt fogyaszt & 1 & 11 & 60 \\
\hline Hetente legalább egyszer részeg & 1 & 4 & 29 \\
\hline Fogyókúrázik & 7 & 17 & 19 \\
\hline Rendszeresen sportol & 65 & 78 & 70 \\
\hline Odafigyel arra, hogy egészségesen táp- & 51 & 47 & 36 \\
\hline lálkozzon & - & 4 & 9 \\
\hline Mäldet, dzsangát, spanglit fogyaszt & - & 8 & 43 \\
\hline Már volt szexuális kapcsolata (lefeküdt & valakivel) & & \\
\hline
\end{tabular}

18. táblázat: Osztálylégkör megitélésének megoszlása (\%)

\begin{tabular}{|c|c|c|c|}
\hline Az osztálylégkör megítélése & 5. osztály (\%) & 7. osztály (\%) & 9. osztály (\%) \\
\hline Negatív & 2 & 2 & 3 \\
\hline Átlagos & 4 & 6 & 6 \\
\hline Nagyon kedvezó & 94 & 92 & 91 \\
\hline
\end{tabular}

\section{ÖSSZEGZÉS}

Az iskolai egészségkommunikációs felmérés úttörő jellegú, hiszen a Michie és munkatársai által kidolgozott COM-B modellt alkalmazta a 11-15 évesek tanulók egészségének és egészségmagatartásának vizsgálatában. ${ }^{31} \mathrm{E}$ szemlélet tükrében a kérdőív tartalmaz olyan hazai vonatkozásban kevéssé vizsgált szegmenseket, mint a diákok egészséggel kapcsolatos ismeretei, hiedelmei, attitúdje, a viselkedést befolyásoló társas környezet részletes jellemzése, továbbá a különböző kommunikációs csatornák használatára vonatkozó információk. Ezen információk segíthetnek a homogén tanulókból álló csoportok profiljának, azaz egészségstílusának meghatározásában.

A válaszok elemzésekor, az eredmények értelmezéskor feltétlenül figyelembe kell venni, hogy az Egészségkommunikációs Felmérésében alkalmazott kérdőív egészében nem tekinthető validáltnak, hiszen azt jó néhány saját fejlesztésű kérdésből vagy a nemzetközi szakirodalomból átvett skálából illetve annak részleteiből állítottuk össze.

A táplálkozás minőségének jó mutatója a különböző ételféleségek aránya az étrendben. Az édességek, a szénsavas, cukortartalmú üdítőitalok (kóla, tonik stb.) és az energiaitalok kalóriában és/vagy élénkítő anyagokban gazdag, de egyéb tápanyagokban szegény élelmiszerek, melyek gátolják a táplálóbb élelmiszerek fogyasztását. A megkérdezett tanulók esetében a tea a leggyakrabban fogyasztott koffein tartalmú ital, az egészségkockázatot jelentő élelmiszerek esetében az édesség a leggyakrabban fogyasztott egészségkockázatot jelentő élelmiszer.

A diákok több mint fele $(52,7 \%)$ legfeljebb 2 órát tévézik hétköznap. A hétvégi napokon naponta 3-4 órás tévénézés a leginkább jellemző $(36,2 \%)$, de minden ötödik fiatal ennél is többet, legalább 5 órát néz tévét naponta hétvégéken.

Az EKF kérdőíve tehát korlátozottan alkalmas más célú elemzések, más felmérések eredményeivel történő összevetésre, többek között a rizikómagatartásokra vonatkozó kérdésfeltevés is eltér és módszertanilag különbözik a magyar serdülók között végzett epidemiológiai vizsgálatoktól. Az alapadatok tekintetében mégis elmondható, hogy a 9. évfolyamosok dohányzás életprevalenciája ${ }^{32}$ hasonló a 2014-es 
HBSC ${ }^{x i i}$ felmérésben, és a 2013-as GYTS ${ }^{\text {xiii }}$ felmérésben a 13-15 éveseknél mért adatokhoz. ${ }^{31,33}$ Valamint, kismértékben, de alacsonyabb az ESPAD ${ }^{\text {xiv }}$ 2011-ben mért eredményéhez képest, amely szerint a 8-10. évfolyamosok kétharmada dohányzott már életében. ${ }^{9} \mathrm{Az}$ egészségkommunikációs felmérés szerint a 9. osztályosok 79\%-a ivott már valaha egy-két kortynál több alkoholt. Ennél magasabbak a legutóbbi HBSC 9. évfolyamosokra (életprevalencia $82,6 \%$ ) és az ESPAD életprevalenciára vonatkozó eredményei (91\%). A 9. osztályosok 11\%-a legalább egyszer fogyasztott már valamilyen drogot. Sajnálatos módon még ennél is magasabb arányt mértek az ismétlődő, nemzetközi kutatások (HBSC: 18,2\%, ESPAD: 19,5\%).

Az egészséggel kapcsolatos témák közül leggyakrabban a mozgás, testedzés témakörben keresnek információt a tanulók. A keresők aránya az életkor növekedésével nő. Évfolyamtól függetlenül majdnem minden témában a családot tartják a legnagyobb arányban hiteles és elsődleges információforrásnak. Általában elmondható, hogy minél idősebb a tanuló, annál ritkábban fordul bizonyos témák kapcsán szüleihez. A leginkább a jövőbeli terveket és a házi feladatot illetően fordulnak szüleikhez. A különböző témák közül a baráti konfliktusok nehézségét és az alkohol, drogok kapcsán felmerült kérdéseket osztják meg a legritkábban. Eredményeink felhívják a figyelmet a további elemzés szükségességére annak részletes feltárására, hogy a szülői kapcsolatok minősége hogyan befolyásolja a serdülőkorúak egészségét és a jóllétének alakulását.

A serdülőkor a társas viszonyok átrendeződésének időszaka. A szülőktől távol, a kortársakkal együtt töltött idő növekedésében tetten érhető a serdülők személyes autonómiájának gyakorlása és identitásuk kialakítása. A kortársak ebben az életkorban fontos modellt nyújtanak és kölcsönösen befolyásolhatják egymás viselkedését, életmódját. Az osztálytársakkal kialakított viszony, a légkör fontos része a fiatalok mindennapjainak, hiszen ebben a közösségben töltik idejük nagy részét az iskolán belül. A rizikómagatartások előfordulási gyakorisága az idősebb tanulók között növekvő tendenciát mutat. A sportoló barátok és osztálytársak magas száma mindhárom korosztályra jellemző, míg az egészségesen táplálkozó kortársak aránya az életkorral csökken.

A bemutatott leíró statisztikai eredmények értelmezésekor feltétlenül figyelembe kell venni, hogy azok önmagukban korlátozottan felhasználhatóak, elsődleges céljuk a széleskörü tájékoztatás. A felmérés adatainak mélyrehatóbb és innovatív elemzésére további publikációkat tervezünk.

\footnotetext{
xii Health Behaviour in School-aged Children

xiii Global Youth Tobacco Survey

xiv European School Survey Project on Alcohol and Other Drugs
} 


\section{FÜGGELÉK}

Viselkedéses

19. táblázat: Médiafogyasztás

\begin{tabular}{|c|c|c|c|c|c|}
\hline \multicolumn{6}{|c|}{ 5. osztály } \\
\hline Médiumok & Semennyit & $\begin{array}{l}\text { Legfeljebb } 2 \\
\text { órát }\end{array}$ & 3-4 órát & $\begin{array}{l}5 \text { vagy több } \\
\text { órát }\end{array}$ & \\
\hline Tv hétköznap & 21 & 55 & 16 & 8 & \\
\hline TV hétvégén & 7 & 34 & 37 & 22 & \\
\hline $\begin{array}{c}\text { Számítógépes játék hét- } \\
\text { köznap }\end{array}$ & 46 & 43 & 8 & 3 & \\
\hline $\begin{array}{c}\text { Számítógépes játék hétvé- } \\
\text { gén }\end{array}$ & 18 & 43 & 25 & 14 & \\
\hline Internet hétköznap & 39 & 45 & 11 & 5 & \\
\hline Internet hétvégén & 16 & 44 & 25 & 15 & \\
\hline Rádiót hallgat hétköznap & 68 & 27 & 3 & 2 & \\
\hline \multirow[t]{2}{*}{ Rádiót hallgat hétvégén } & 55 & 34 & 7 & 4 & \\
\hline & Soha & $\begin{array}{l}\text { Nagyon ritkán } \\
\text { (évente) }\end{array}$ & $\begin{array}{l}\text { Időnkén (ne- } \\
\text { gyedévente) }\end{array}$ & $\begin{array}{l}\text { Rendszeresen } \\
\text { (Havonta leg- } \\
\text { alább 1-et) }\end{array}$ & \\
\hline Könyvet olvas hétköznap & 27 & 19 & 22 & 33 & \\
\hline \multirow[t]{2}{*}{ Könyvet olvas hétvégén } & 23 & 18 & 24 & 35 & \\
\hline & Soha & $\begin{array}{l}\text { Ritkábban, } \\
\text { mint hetente }\end{array}$ & $\begin{array}{l}\text { Hetente 1-2 na- } \\
\text { pon }\end{array}$ & Heti 2-4 napon & Minden nap \\
\hline Újságot olvas hétköznap & 50 & 24 & 14 & 7 & 5 \\
\hline Újságot olvas hétvégén & 44 & 29 & 15 & 7 & 5 \\
\hline \multicolumn{6}{|c|}{ 7. osztály } \\
\hline Médiumok & Semennyit & $\begin{array}{l}\text { Legfeljebb } 2 \\
\text { órát }\end{array}$ & 3-4 órát & $\begin{array}{l}5 \text { vagy több } \\
\text { órát }\end{array}$ & \\
\hline Tv hétköznap & 18 & 55 & 19 & 8 & \\
\hline TV hétvégén & 7 & 34 & 37 & 22 & \\
\hline $\begin{array}{c}\text { Számítógépes játék hét- } \\
\text { köznap }\end{array}$ & 41 & 42 & 12 & 5 & \\
\hline $\begin{array}{c}\text { Számítógépes játék hétvé- } \\
\text { gén }\end{array}$ & 24 & 32 & 24 & 20 & \\
\hline Internet hétköznap & 16 & 52 & 20 & 13 & \\
\hline Internet hétvégén & 6 & 35 & 31 & 28 & \\
\hline Rádiót hallgat hétköznap & 66 & 29 & 3 & 2 & \\
\hline \multirow[t]{2}{*}{ Rádiót hallgat hétvégén } & 56 & 33 & 7 & 4 & \\
\hline & Soha & $\begin{array}{l}\text { Nagyon ritkán } \\
\text { (évente) }\end{array}$ & $\begin{array}{l}\text { Időnkén (ne- } \\
\text { gyedévente) }\end{array}$ & $\begin{array}{c}\text { Rendszeresen } \\
\text { (Havonta leg- } \\
\text { alább 1-et) }\end{array}$ & \\
\hline Könyvet olvas hétköznap & 32 & 20 & 24 & 25 & \\
\hline \multirow[t]{2}{*}{ Könyvet olvas hétvégén } & 29 & 19 & 23 & 29 & \\
\hline & Soha & $\begin{array}{l}\text { Ritkábban, } \\
\text { mint hetente }\end{array}$ & $\begin{array}{l}\text { Hetente 1-2 na- } \\
\text { pon }\end{array}$ & Heti 2-4 napon & Minden nap \\
\hline Újságot olvas hétköznap & 39 & 31 & 18 & 7 & 5 \\
\hline Újságot olvas hétvégén & 35 & 45 & 27 & 9 & 5 \\
\hline
\end{tabular}




\begin{tabular}{|c|c|c|c|c|c|}
\hline \multicolumn{6}{|c|}{ 9. osztály } \\
\hline Médiumok & Semennyit & $\begin{array}{l}\text { Legfeljebb } 2 \\
\text { órát }\end{array}$ & 3-4 órát & $\begin{array}{l}5 \text { vagy több } \\
\text { órát }\end{array}$ & \\
\hline Tv hétköznap & 32 & 44 & 19 & 5 & \\
\hline TV hétvégén & 14 & 34 & 34 & 18 & \\
\hline $\begin{array}{c}\text { Számítógépes játék hétköz- } \\
\text { nap } \\
\end{array}$ & 52 & 30 & 12 & 6 & \\
\hline $\begin{array}{c}\text { Számítógépes játék hétvé- } \\
\text { gén }\end{array}$ & 38 & 22 & 20 & 20 & \\
\hline Internet hétköznap & 6 & 41 & 29 & 25 & \\
\hline Internet hétvégén & 3 & 23 & 32 & 43 & \\
\hline Rádiót hallgat hétköznap & 68 & 28 & 3 & 2 & \\
\hline \multirow[t]{2}{*}{ Rádiót hallgat hétvégén } & 57 & 32 & 8 & 3 & \\
\hline & Soha & $\begin{array}{l}\text { Nagyon ritkán } \\
\text { (évente) }\end{array}$ & $\begin{array}{l}\text { Időnkén (ne- } \\
\text { gyedévente) }\end{array}$ & $\begin{array}{l}\text { Rendszeresen } \\
\text { (Havonta leg- } \\
\text { alább 1-et) }\end{array}$ & \\
\hline Könyvet olvas hétköznap & 36 & 21 & 22 & 21 & \\
\hline \multirow[t]{2}{*}{ Könyvet olvas hétvégén } & 32 & 21 & 23 & 24 & \\
\hline & Soha & $\begin{array}{l}\text { Ritkábban, } \\
\text { mint hetente }\end{array}$ & $\begin{array}{l}\text { Hetente } 1-2 \\
\text { napon }\end{array}$ & Heti 2-4 napon & Minden nap \\
\hline Újságot olvas hétköznap & 39 & 35 & 16 & 5 & 4 \\
\hline Újságot olvas hétvégén & 35 & 39 & 16 & 6 & 4 \\
\hline
\end{tabular}

Környezet

20. táblázat: Szülői kapcsolatok megitélésének megoszlása (\%)

\begin{tabular}{|c|c|c|c|c|c|}
\hline & Szinte soha & Nem gyakran & Néha & Gyakran & Szinte mindig \\
\hline $\begin{array}{c}\text { nehézségeid lennének a } \\
\text { házi feladattal, }\end{array}$ & 9 & 14 & 41 & 21 & 15 \\
\hline $\begin{array}{c}\text { szeretnél találni egy jó } \\
\text { könyvet vagy filmet, }\end{array}$ & 12 & 15 & 30 & 27 & 16 \\
\hline $\begin{array}{c}\text { a jövöbeli terveiden gon- } \\
\text { dolkoznál, }\end{array}$ & 13 & 17 & 25 & 22 & 22 \\
\hline $\begin{array}{c}\text { összevesznétek a legjobb } \\
\text { barátoddal, }\end{array}$ & 36 & 19 & 21 & 12 & 12 \\
\hline $\begin{array}{c}\text { szeretnél valamit megtudni } \\
\text { az alkoholról vagy drogok- } \\
\text { ról, }\end{array}$ & 72 & 8 & 8 & 4 & 8 \\
\hline $\begin{array}{c}\text { igazán mérges lennél vagy } \\
\text { kiborulnál valami miatt, }\end{array}$ & 11 & 24 & 30 & 19 & 16 \\
\hline $\begin{array}{c}\text { valami miatt rosszul érez- } \\
\text { néd magad vagy búntuda- } \\
\text { tod lenne. }\end{array}$ & 13 & 18 & 29 & 20 & 20 \\
\hline $\begin{array}{r}\text { nehézségeid lennének a } \\
\text { házi feladattal, }\end{array}$ & 14 & 18 & 40 & 18 & Szinte mindig \\
\hline $\begin{array}{c}\text { szeretnél találni egy jó } \\
\text { könyvet vagy filmet, }\end{array}$ & 20 & 20 & 29 & 24 & 10 \\
\hline
\end{tabular}




\begin{tabular}{|c|c|c|c|c|c|}
\hline $\begin{array}{c}\text { a jövőbeli terveiden gon- } \\
\text { dolkoznál, }\end{array}$ & 7 & 11 & 25 & 34 & 22 \\
\hline $\begin{array}{c}\text { összevesznétek a legjobb } \\
\text { barátoddal, }\end{array}$ & 40 & 21 & 20 & 11 & 8 \\
\hline $\begin{array}{l}\text { szeretnél valamit megtudni } \\
\text { az alkoholról vagy drogok- } \\
\text { ról, }\end{array}$ & 55 & 16 & 14 & 7 & 8 \\
\hline $\begin{array}{l}\text { igazán mérges lennél vagy } \\
\text { kiborulnál valami miatt, }\end{array}$ & 16 & 20 & 30 & 21 & 13 \\
\hline $\begin{array}{l}\text { valami miatt rosszul érez- } \\
\text { néd magad vagy büntuda- } \\
\text { tod lenne. }\end{array}$ & 17 & 20 & 28 & 20 & 16 \\
\hline \multicolumn{6}{|c|}{ 9. osztály } \\
\hline & Szinte soha & Nem gyakran & Néha & Gyakran & Szinte mindig \\
\hline $\begin{array}{l}\text { nehézségeid lennének a } \\
\text { házi feladattal, }\end{array}$ & 25 & 23 & 36 & 11 & 6 \\
\hline $\begin{array}{l}\text { szeretnél találni egy jó } \\
\text { könyvet vagy filmet, }\end{array}$ & 30 & 23 & 25 & 16 & 6 \\
\hline $\begin{array}{c}\text { a jövőbeli terveiden gon- } \\
\text { dolkoznál, }\end{array}$ & 9 & 13 & 29 & 31 & 17 \\
\hline $\begin{array}{c}\text { összevesznétek a legjobb } \\
\text { barátoddal, }\end{array}$ & 40 & 18 & 18 & 14 & 10 \\
\hline $\begin{array}{c}\text { szeretnél valamit megtudni } \\
\text { az alkoholról vagy drogok- } \\
\text { ról, }\end{array}$ & 49 & 19 & 16 & 9 & 7 \\
\hline $\begin{array}{l}\text { igazán mérges lennél vagy } \\
\text { kiborulnál valami miatt, }\end{array}$ & 19 & 21 & 25 & 20 & 15 \\
\hline $\begin{array}{l}\text { valami miatt rosszul érez- } \\
\text { néd magad vagy büntuda- } \\
\text { tod lenne. }\end{array}$ & 22 & 21 & 25 & 17 & 15 \\
\hline
\end{tabular}

21. táblázat: Szülői kontroll megitélésének megoszlása (\%)

\begin{tabular}{|c|c|c|c|c|c|}
\hline \multicolumn{6}{|c|}{ 5. osztály } \\
\hline & $\begin{array}{l}\text { Nem szoktam } \\
\text { ilyet csinálni }\end{array}$ & $\begin{array}{l}\text { Nem is tudnak } \\
\text { róla }\end{array}$ & $\begin{array}{l}\text { Tudnak róla, } \\
\text { de nem érdekli } \\
\text { öket }\end{array}$ & $\begin{array}{l}\text { Tudnak róla, } \\
\text { de rám bízzák } \\
\text { a döntést }\end{array}$ & $\begin{array}{l}\text { Tudnak róla és } \\
\text { korlátozzák } \\
\text { vagy tiltják }\end{array}$ \\
\hline $\begin{array}{l}\text { mikor és mennyit tévézel, } \\
\text { internetezel }\end{array}$ & 3 & 2 & 5 & 40 & 51 \\
\hline mikorra kell hazaérned & 0 & 2 & 4 & 37 & 56 \\
\hline mennyi édességet eszel & 6 & 3 & 7 & 33 & 52 \\
\hline mivel töltöd a szabadidódet & 0 & 3 & 8 & 72 & 17 \\
\hline kikkel barátkozol & 0 & 2 & 8 & 74 & 16 \\
\hline mennyit dohányzol & 94 & 1 & 0 & 1 & 4 \\
\hline $\begin{array}{l}\text { mennyi alkoholt fogyasz- } \\
\text { tasz }\end{array}$ & 92 & 0 & 0 & 1 & 6 \\
\hline \multicolumn{6}{|c|}{ 7. osztály } \\
\hline & $\begin{array}{l}\text { Nem szoktam } \\
\text { ilyet csinálni }\end{array}$ & $\begin{array}{l}\text { Nem is tudnak } \\
\text { róla }\end{array}$ & $\begin{array}{l}\text { Tudnak róla, } \\
\text { de nem érdekli } \\
\text { őket }\end{array}$ & $\begin{array}{l}\text { Tudnak róla, } \\
\text { de rám bízzák } \\
\text { a döntést }\end{array}$ & $\begin{array}{l}\text { Tudnak róla és } \\
\text { korlátozzák } \\
\text { vagy tiltják }\end{array}$ \\
\hline $\begin{array}{c}\text { mikor és mennyit tévézel, } \\
\text { internetezel }\end{array}$ & 3 & 1 & 5 & 54 & 38 \\
\hline mikorra kell hazaérned & 0 & 1 & 2 & 38 & 58 \\
\hline
\end{tabular}




\begin{tabular}{|c|c|c|c|c|c|}
\hline mennyi édességet eszel & 6 & 3 & 8 & 51 & 33 \\
\hline mivel töltöd a szabadidődet & 0 & 3 & 9 & 75 & 13 \\
\hline kikkel barátkozol & 0 & 3 & 7 & 76 & 13 \\
\hline mennyit dohányzol & 90 & 3 & 0 & 2 & 5 \\
\hline $\begin{array}{c}\text { mennyi alkoholt fogyasz- } \\
\text { tasz }\end{array}$ & 85 & 3 & 0 & 3 & 9 \\
\hline \multicolumn{6}{|c|}{ 9. osztály } \\
\hline & $\begin{array}{l}\text { Nem szoktam } \\
\text { ilyet csinálni }\end{array}$ & $\begin{array}{l}\text { Nem is tudnak } \\
\text { róla }\end{array}$ & $\begin{array}{l}\text { Tudnak róla, } \\
\text { de nem érdekli } \\
\text { őket }\end{array}$ & $\begin{array}{l}\text { Tudnak róla, } \\
\text { de rám bízzák } \\
\text { a döntést }\end{array}$ & $\begin{array}{c}\text { Tudnak róla és } \\
\text { korlátozzák } \\
\text { vagy tiltják }\end{array}$ \\
\hline $\begin{array}{l}\text { mikor és mennyit tévézel, } \\
\text { internetezel }\end{array}$ & 3 & 1 & 7 & 70 & 19 \\
\hline mikorra kell hazaérned & 0 & 1 & 3 & 47 & 49 \\
\hline mennyi édességet eszel & 7 & 2 & 16 & 60 & 15 \\
\hline mivel töltöd a szabadidődet & 0 & 4 & 8 & 77 & 12 \\
\hline kikkel barátkozol & 0 & 4 & 8 & 81 & 8 \\
\hline mennyit dohányzol & 72 & 9 & 2 & 10 & 7 \\
\hline $\begin{array}{c}\text { mennyi alkoholt fogyasz- } \\
\text { tasz }\end{array}$ & 54 & 10 & 2 & 18 & 17 \\
\hline
\end{tabular}

\footnotetext{
${ }^{1}$ Investing in children: the European child and adolescent health stategy 2015-2020. Copenhagen. WHO Regional Office for Europe. 2014

http://www.euro.who.int/ data/assets/pdf file/0010/253729/64wd12e InvestCAHstrategy 140440.pdf?ua=1 (Elérve: 2016.08.29.)

2 Inchley J, Currie D. (2013). Growing up unequal: gender and socioeconomic differences in young people's health and well-being. Health Behaviour in School-aged Children (HBSC) Study: International report from the 2013-2014 Survey ${ }^{3}$ Németh Á, Költő A. (Szerk.), Egészség és egészségmagatartás iskoláskorban 2014. Az Iskoláskorú gyermekek egészségmagatartása elnevezésű, az Egészségügyi Világszervezettel együttmúködésben megvalósuló nemzetközi kutatás 2014. évi felméréséről készült nemzeti jelentés.Budapest.Nemzeti Egészségfejlesztési Intézet.

http://www.egeszseg.hu/szakmai oldalak/assets/cikkek/16-05/egeszseg-es-egeszsgegmagatartas-iskolaskorban2014.pdf (Elérve: 2016.08.29.)

${ }^{4}$ Michie S, van Stralen MM, West R. The behaviour change wheel: a new method for characterising and designing behaviour change interventions. Implement Science. 2011;6:42. doi:10.1186/1748-5908-6-42

${ }^{5}$ Balku E, Berki J, Csizmadia P, et al (2015) Health Riport. National Institute for Health Development

${ }^{6}$ Balku E, Vitrai J (2016) Egészségkommunikációs Felmérés Eredményei I.-Felnőtt felmérés. Egészségfejlesztés, 57 . évf. 2. szám (2016)

${ }^{7}$ World Health Organization. WHO Report on the Global Tobacco Epidemic. Geneva, Switzerland. World Health Organization. 2013

${ }^{8}$ ESPAD 2011: Hibell B, Guttormsson U, Ahlström S, Balakireva O, Bjarnason T, Kokkevi A, Kraus L.. The 2011 ESPAD report. 2012

${ }^{9}$ Elekes Zs.: Egy változó kor változó ifjúsága: Fiatalok alkohol- és egyéb drogfogyasztása Magyarországon. ESPAD 2007. L'Harmattan. Budapest. 2009.

${ }^{10}$ Buhi ER, Daley EM, Fuhrmann HJ, Smith S. An observational study of how young people search for online sexual health information. J Am Coll Health 2009:58:101-11. doi: 10.1080/07448480903221236

${ }^{11}$ Goldberg DP, Hillier VF. A scaled version of the General Health Questionnaire. Psychol Med 1979: 9:139-145. doi: 10.1017/S0033291700021644

12 Örkényi Á, Kökönyei Gy. Szenzoros élménykeresés. In. Serdülőkorú fiatalok egészsége és életmódja 2010. Az Iskoláskorú Gyermekek Egészségmagatartása című, az Egészségügyi Világszervezettel együttműködésben zajló nemzetközi kutatás 2010. évi felméréséről készült nemzeti jelentés. Budapest, 2011. Országos Gyermekegészségügyi Intézet.
} 
${ }^{13}$ Schwarzer R, Jerusalem M. In. Wright JWS, Johnston M. Measures in health psychology: A user's portfolio. Causal and control beliefs. Windsor, UK: NFER-NELSON 1995: 35-37. doi: 10.1037/t00393-000Macías YF, Glasauer P. Guidelines for assessing nutrition-related Knowledge, Attitudes and Practices. Food and Agriculture Organization of the United Nations. Rome. 2014

${ }^{14}$ Abbott R, Macdonald D, Stubbs C, et al. Healthy Kids Queensland Survey 2006 - Full Report, 2008

${ }^{15}$ Smolak L, Levine MP. Toward an Empirical Basis for Primary Prevention of Eating Problems with Elementary School Children. Eat Disord J Treat Prev 1994: 2:293-307. doi: 10.1080/10640269408249128

${ }^{16}$ Cantril H. The pattern of human concerns. Rutgers Un. New Brunswick, New Jersey, USA. 1965

${ }^{17}$ Urbán R, Czeglédi E, Kovács K, Kelemen A. A szenzoros élménykeresés összefüggése az alkoholfogyasztással és az alkohollal kapcsolatos elvárásokkal középiskolások körében. Magyar Pszichológiai Szemle. 2008: 63(3): 499-518.

${ }^{18}$ Rokeach M. Rokeach Values Survey, 1973.

${ }^{19}$ Pikó B . Value orientation and health behavior in adolescents. Iskolakultúra 2008: 62-86.

${ }^{20}$ Kasser T, Ryan RM.Further Examining the American Dream: Differential Correlates of Intrinsic and Extrinsic Goals. Personal Soc Psychol Bull 1996: 22:280-287. doi: 10.1177/0146167296223006

${ }^{21}$ Huebner E, Laughlin JE, Ash C, Gilman R. Further validation of the Multidimensional Students' Life Satisfaction Scale. J Psychoeduc Assess 1998: 16:118-134. doi: 10.1177/073428299801600202

22 OECD (2009) PISA 2006 Technical Report

${ }^{23}$ Zabriskie RB, McCormick BP. The influences of family leisure patterns on perceptions of family functioning. Fam Relat 2001: 50:281-289. doi: 10.1111/j.1741-3729.2001.00281.x

${ }^{24}$ Israel AC, Roderick H A, IvanovaMY. A measure of the stability of activities in a family environment. Journal of Psychopathology and Behavioral Assessment. 2002: 24, 85-95.

${ }^{25}$ Sillars A, Koerner A, Fitzpatrick MA. Communication and understanding in parent-adolescent relationships. Hum. Commun. Res. 2005: 31:102-128.

${ }^{26}$ Jessor R, In Bonino S, Cattelino E, Ciairano S.Adolescents and Risk: Behaviors, Functions, and Protective Factors. New York. 2005

${ }^{27}$ Costa FM, Jessor R, Turbin MS, et al.The Role of Social Contexts in Adolescence: Context Protection and Context Risk in the United States and China. Appl Dev Sci 2005: 9:67-85. doi: 10.1207/s1532480xads0902_3

${ }^{28}$ Zuckerman M. Behavioral expressions and biosocial bases of sensation seeking. Cambridge university press. Elgar FJ, Craig W, Trites S J. (2013). Family dinners, communication, and mental health in Canadian adolescents. Journal of Adolescent Health. 1994: 52(4): 433-438.

${ }^{29}$ Eriksson I, Cater $\AA$ Andershed AK, Andershed H. What protects youths from externalising and internalising problems? A critical review of research findings and implications for practice. Australian Journal of Guidance and Counselling. 2011: 21(2):113-125.

${ }^{30}$ Michie S, van Stralen M, West R The behaviour change wheel: A new method for characterising and designing behaviour change interventions. Implementation Science. 2011: 6:42.

${ }^{31}$ Arnold P. Rizikómagatartások. In Németh Á. \& Költő A. (Szerk.), Egészség és egészségmagatartás iskoláskorban 2014. Az Iskoláskorú gyermekek egészségmagatartása elnevezésű, az Egészségügyi Világszervezettel együttmúködésben megvalósuló nemzetközi kutatás 2014. évi felméréséről készült nemzeti jelentés. Nemzeti Egészségfejlesztési Intézet. Budapest. 2016.

32 Balku E, Demjén T, Kimmel Zs, Vitrai J. Nemzetközi Ifjúsági Dohányzás Felmérés Egészségügyi Világszervezet. Dohányzás Fókuszpont, Országos Egészségfejlesztési Intézet. Budapest. 2013.

33 http://www.egeszseg.hu/szakmai_oldalak/oldal/szakmai-anyagok/szakmai-anyagok-egeszsegkommunikaciosfelmeres/ (Elérve: 2016.08.29.) 